\title{
Coade, Blashfield or Doulton? \\ The in-situ identification of ceramic garden statuary and ornament from three eighteenth and nineteenth century manufacturers.
}

\author{
Laura E. Karran \\ Visiting Researcher \\ School of Chemistry \\ University of Lincoln \\ Brayford Pool \\ Lincoln LN6 7TS, UK \\ T: +44 1223313380 \\ E: Ik208@cam.ac.uk \\ Belinda J Colston* \\ Professor of Analytical Chemistry and Cultural Heritage \\ School of Chemistry, \\ University of Lincoln, \\ Brayford Pool, \\ Lincoln LN6 7TS, UK \\ T: +44 1522837448 \\ E: bcolston@lincoln.ac.uk \\ Corresponding author
}

\begin{abstract}
In the eighteenth century, the emergence of a neo-classical style in architecture created a growing demand for a range of classically-inspired products - not only for architectural decoration but also for ornamentation of the garden. Producing individual items in stone, however, was time-consuming and expensive, so cheaper clay-based alternatives were adopted, most notably from manufacturers such as Coade (1769-1830), Blashfield (1840s-1875) and Doulton (1854-1890s).

The artefacts of these manufacturers are now considered of high historic value and significance and their identification is important, not only for the historical record, but also for provision of the evidence necessary to carry out informed conservation. As the sale and copy of moulds was common practice during the eighteenth and nineteenth centuries, stylistic considerations do not provide reliable identification.
\end{abstract}

Through the analysis of 24 historic objects of garden statuary and ornamentation, this research evaluates the use of portable X-ray fluorescence spectroscopy (pXRF), and more specifically element profiles, in identifying, and differentiating between the products of Coade, Blashfield and Doulton. Key questions around heterogeneity and representative material analysis are addressed.

Despite the inherent heterogeneity of these materials, it is shown that discrimination is nevertheless possible using pXRF, primarily due to the significant differences observed across a range of elements at both macro- and trace-level. Objects of known provenance from Coade, Blashfield and Doulton produced three distinct and statistically significant groups demonstrating that the data reflect the composition of the bulk material - rather than surface characteristics.

Through identifying the main discriminators for the Coade, Blashfield and Doulton materials, a simple presumptive test is proposed that can be used in an initial evaluation of any unsigned works. 
Analysis of a selection of unsigned objects with a probable Coade, Blashfield or Doulton provenance was in many cases successful in confirming the documentary evidence. A few objects, however, presented anomalous element profiles. These most likely result from past conservation treatments or polychromy - the two major limitations of the technique.

\section{Keywords}

Coade stone, Blashfield, Doulton, portable x-ray fluorescence spectroscopy, element profiling, artificial stone, stoneware, terracotta.

\section{Research Aims}

This research aims to evaluate the use of pXRF, and more specifically element profiles, in identifying, and differentiating between, the products of three key manufacturers of ceramic garden statuary and ornament during the eighteenth and nineteenth centuries. As the sale and copy of moulds was common practice during this time, stylistic considerations cannot be reliably used to identify the manufacturer. It is presumed, however, that the manufacturers adopted different recipes, leading to unique element profiles for their wares.

The research aims to establish the reliability of the portable technique in establishing truly representative element profiles of the bulk material in large statuary and urns through routine spot analyses $\left(50.3 \mathrm{~mm}^{2}\right)$ of the surface layer only, thus determining whether a simple, widely accessible, non-invasive methodology can provide useful information in cases where the manufacturer is unknown.

\section{Introduction}

In the eighteenth century, the emergence of a neo-classical style in architecture created a growing demand for a range of classically-inspired products - not only for architectural decoration but also for ornamentation of the garden [1]. Producing individual items in stone, however, was time-consuming and expensive, so the advantages of finding a cheaper alternative were rapidly recognised.

The possibility of using a clay-based material - which could be moulded and fired in a kiln and easily replicated - was a natural development of the efforts being made throughout Europe to reproduce the imported Chinese porcelains. John Dwight of Fulham, for example, had taken out a patent in 1672 for a material which he claimed to be porcelain although documentary evidence and later analysis now show it to have been 'a white stoneware based upon ball clay, sand and an alkaline glass frit' [2]. Dwight's material was commercially unsuccessful but, by the early eighteenth century, the potential of combining clay with a glass flux to create an 'artificial stone' was recognised by manufacturers such as Richard Holt. His production of a vitrified ceramic body was documented in 1732 and the process was successfully developed by Mrs Eleanor Coade in the later part of the eighteenth century.

The stoneware ceramic introduced by Eleanor Coade in 1769 was called Coade stone [3]. Using a ball clay from Dorset, the material produced at her Lambeth factory varied in colour between a pale greyish-white and a light yellow or beige and was identifiable by the presence of a 'Coade, London' or 'Coade, Lambeth' stamp (up to 1799), and a 'Coade \& Sealy' stamp (1799-1830) [4].

It was the popularity of the Coade product which resulted in a number of other manufacturers employing clay-based materials in a similar way. John Marriott Blashfield initially owned a 
manufactory at Millwall where, like Eleanor Coade, he used a ball clay from Dorset, but by 1858 he had moved to Stamford to make use of the good ball clay there [5]. He patented the addition of coprolites and fossil bone to his clays to improve the quality of his products [6], which ranged in colour from light yellow or beige to a dull orange. Up to 1872 his works were identified by the indentations 'Blashfield, Stamford' or 'J.M. Blashfield, Stamford'. At this time the firm was declared bankrupt but was resurrected as 'The Stamford Terra Cotta Company (Blashfield's) Ltd'. Nevertheless, the firm was finally liquidated in 1875 as a result of cheaper ceramic materials being produced elsewhere.

One of the firms producing cheaper products was Doulton, which used a ball clay from the South coast to produce an ever increasing selection of clay-based ornaments. These wares showed a much greater variation in colour, ranging from a pale buff to a deep red, and up to 1890 were stamped 'Doulton, Lambeth'. After this time the firm's name and stamp changed to 'Doulton \& Co Limited'.

As well as a ceramic substitute for stone, another alternative introduced in the nineteenth century was based on a form of cement which could be cast and hardened without the application of heat. Portland cement had been patented by Joseph Aspdin in 1824 and manufacturers of a cement-based substitute for stone included the partnership of Austin and Seeley (1840s-1870s). The contemporary architect and garden designer, Charles Barry, described the material produced by this partnership as a mixture of Portland cement, broken stone, pounded tile and course sand [7]. It varied in colour from a dull grey-white to a light brown yellow and if not indented with the makers' mark is often indistinguishable from stone. Another manufacturer successfully producing a cementbased substitute for stone was James Pulham. His manufactory was established at Broxbourne in 1843 where he also produced a clay-based material [8].

However, unlike many of these later ceramic materials, Coade stone has proved to be the most durable, with its stability attributed to the high firing temperatures and highly vitrified nature of the material - from the presence of a soda-lime-silica glass additive [9].

Nevertheless, the artefacts produced by all these manufacturers are now considered of high historic value and significance and their identification is important, not only for the historical record, but also for provision of the evidence necessary to carry out informed conservation. Although many of the products made for ornamentation of the garden were stamped with a manufacturer's mark (Fig. 1), some have no indentation, making scientific identification necessary.

Portable X-ray fluorescence has become an important addition to the heritage science toolkit. Being both portable and non-destructive, it has been widely utilised across a range of heritage materials including both metals [10] and paint [11], as well as ceramics [12, 13] - providing rapid in-situ elemental analysis.

\section{Experimental details}

\subsection{Sample Selection}

Twenty-four historic ceramic objects (Table 1) from different eighteenth and nineteenth century manufacturers (Figure 2) were chosen for analysis. Fifteen of the objects had clear provenance (manufacturer's signature) and eight objects were unsigned works, but with documentary evidence indicating a probable manufacturer. For comparison, one cementitious object signed by Austin and Seeley was also selected.

\subsection{Element Profiling}

Non-destructive in-situ element profiling was achieved using X-ray fluorescence with field portable energy-dispersive spectrometry (Thermo Scientific, Niton XL3t GOLDD). The handheld instrument 
utilised a miniature silver anode $\mathrm{X}$-ray tube (maximum voltage $50 \mathrm{kV}$ ) as the source of primary radiation, collimated to create a beam of $8 \mathrm{~mm}$ diameter, and a geometrically optimised large drift detector (GOLDD) to detect the characteristic secondary X-rays. The detector was thermoelectrically cooled (Peltier) to approximately $-30^{\circ} \mathrm{C}$. The helium purge system was not used for this research.

Analysis was carried out using the pre-calibrated 'mining mode' - calibration effected through the principle of fundamental parameter calibration - and optimised for both heavier and lighter elements using a combination of four filters to enhance the fluorescence-Main Filter 1 (aluminium and iron) for transition metals; Low Filter 2 (molybdenum) for elements $Z=19-24$; High Filter 3 (copper) for elements $\mathrm{Z}=47-56$; and Light Filter 4 (blank) for elements $\mathrm{Z}<17$ ). Each analysis was of 120 s duration (30s on each filter), and at least six analysis points ( $n=6-12$ ) were selected on each object.

Due to the nature of ceramic objects, a number of considerations, such as surface morphology, the presence of surface organic coatings and material heterogeneity, were taken into account when selecting the location and number of analysis points [14]. Analysis was carried out on surfaces that showed no evidence of polychromy, and were flat or convex to ensure good contact between the object and the analytical window of the spectrometer.

Values for 26 elements - Ba, Sn, Nb, Zr, Sr, Rb, Bi, As, Pb, W, Zn, Cu, Ni, Co, Fe, Mn, Cr, V, Ti, Ca, K, $\mathrm{Al}, \mathrm{P}, \mathrm{Si}, \mathrm{Cl}, \mathrm{S}$ - were recorded.

\subsection{Data Analysis}

Element profiles were established for all samples, which comprised 26 elements in major, minor and trace concentrations. Prior to multivariate analysis, the dataset was transformed using z-score standardisation, to remove any bias due to the wide range of concentrations present.

Cluster analysis and principal component analysis (PCA) were used (ClustanGraphics 8) to establish similarities and differences between samples within the dataset. Statistical significance was tested using one-way ANOVA (Minitab 15 statistical software) with Tukey pairwise comparisons (95\% simultaneous confidence intervals).

\section{Results and Discussion}

\section{Establishing characteristic element profiles}

A comparison of elemental concentrations obtained from multiple areas of the same object $(n=6-12)$ indicated that a number of elements were not being measured with good precision ( $>20 \% \mathrm{RSD}$ ) (Table 2). Many of these elements (e.g. $\mathrm{Sn}, \mathrm{As}, \mathrm{Zn}, \mathrm{Cu}, \mathrm{Ni}$ and $\mathrm{Cr}$ ) were present in trace concentrations (0-100 ppm), approaching the detection limits of the pXRF. Measurement errors for these elements were thus expected to be elevated. Furthermore, poor precision in the more abundant elements (e.g. Al, $\mathrm{Si}$ and $\mathrm{Ca}$ ) indicated heterogeneity within the material itself. Nevertheless, a number of elements were measured with good consistency $(\mathrm{Ba}, \mathrm{Nb}, \mathrm{Zr}, \mathrm{Sr}, \mathrm{Rb}, \mathrm{Fe}$, $\mathrm{Mn}$ and Ti). Although establishing homogeneous element profiles would be the ideal for successful discrimination between different manufacturers, it is not necessarily essential: if differences between the discriminant elements are significantly larger than the spread of data within the element profiles, then differentiation can still be effected with statistical significance.

With the pXRF being a surface analysis technique, it is important to establish whether the surface composition is representative of the bulk material, and not a reflection of the external environment to which the objects have been exposed. It is known that Coade, Blashfield and Doulton used different recipes for manufacturing their ceramic materials, including different proportions of sand and clay. If the surface composition is a reflection of the bulk material it would be expected, to a first 
approximation, that differentiation between Coade, Doulton and Blashfield could be achieved with a bielemental plot of $\mathrm{Si}$ (sand) against Fe (clay mineral). From the data presented in Figure 3, it would seem that PXRF data, although only surface information, is likely to reflect the composition of the bulk material, and a multivariate statistical approach should establish a more robust discrimination.

Principal Component Analysis (PCA) of a 24-element data set (W and Co having been removed from the original data set due to their absence in all samples) was carried out for all the signed works by Coade, Blashfield, Doulton and Austin \& Seeley (Fig.4). Despite the heterogeneity in composition and poor reproducibility of trace element concentrations, ceramic artefacts from the four manufacturers were readily differentiated through distinct element profiles. Notable differences in the Coade material are centred on a relatively low iron content $(0.62 \% \mathrm{cf} .0 .98-1.02 \%)$ and the absence of bismuth (exclusively lower than detection limits). The Blashfield is characterised by a relatively high zirconium content $(0.035 \%$ cf. $0.018-0.019 \%)$, and low concentrations of both barium $(0.036 \% \mathrm{cf}$. $0.048-0.054 \%$ ) and aluminium (1.5\% cf. $2.9-5.0 \%)$, whilst the Doulton typically contains high levels of phosphorus (0.40\% cf. $0.082-0.124 \%$ ). As expected, the cementitious Austin \& Seeley product was significantly different in composition, most notably in its calcium content - an order of magnitude higher than the other three fabrics (30\% cf. 1.6-3.1\%) - and also the low silicon concentrations (6.8\% cf. $26-31 \%)$.

Ten principal discriminating elements were identified for the Coade, Blashfield and Doulton materials (Fig.5a). Statistical significance was confirmed using one-way ANOVA, with pairwise comparisons effected through Tukey tests ( $95 \%$ simultaneous confidence intervals). The pairwise comparisons are summarised in Table 3.

By considering the discriminators and the overall measurement precision, it was possible to differentiate the three materials by a simple bivariate plot of element ratios (mean concentration). The two ratios chosen $(\mathrm{Sr} / \mathrm{Fe}$ and $\mathrm{Rb} / \mathrm{Zr}$ ) were considered the most appropriate as all four of these elements were determined consistently with good precision (RSD $<10 \%$ ) for all objects analysed (Fig.5b). This may provide a simple test for the initial evaluation of unsigned works.

\section{Comparison of unsigned works}

Once the characteristic element profiles for the Coade, Doulton and Blashfield products were established, comparisons were made with the unsigned works to determine their manufacturer.

Documentary evidence [4] indicates that a number of the unsigned artefacts are of Coade origin: the Gate Pier from Mrs Coade's villa in Lyme Regis, the Sphinx from Croome Park and the Statue of George III at Lincoln. Although PCA analysis (Fig. 6) confirmed that both the gate pier and the Sphinx were manufactured from Coade stone - also reflected in the bivariate plot of element ratios (Fig.5b) - the PCA results for the statue of George III were not totally as expected.

This is explained, however, by considering the interesting history of this piece. Documentary evidence [8] suggests that it was created in 1810 by Joseph Panzetta who was one of the chief sculptors for the Coade firm in the early nineteenth century. Initially it stood on top of a tall pillar at Dunston, Lincolnshire, but in 1940 - having been deemed a danger to aircraft landing in a nearby airfield - the statue and pillar were knocked down. The bust survived and following conservation was erected in the garden of Lincoln Castle. The legs, however, remain in pieces in the Castle cellar and are clearly still in their original condition. The PCA confirmed the legs to be Coade stone but the results for the bust could not confirm the Coade identity (Fig.6). Similarly the bivariate plot placed the legs with the Coade group, but the bust was shown to be closer to Doulton. This was entirely due to an elevated iron content ( $1.10 \% \mathrm{cf} .0 .62 \%$ in Coade) present in the bust. Also revealed was the presence of bismuth $(0.006 \%)$, absent in the signed Coade works studied. In addition to these two 
deviations from the characteristic Coade composition, significantly elevated levels of manganese, chromium and titanium (by an order of magnitude) were observed, along with only half the expected silicon. Following further investigation, it was discovered that the conservation of the bust included the use of a modern version of Coade stone to replace damaged areas with a wash of a mineral paint to mask joins and additions. This is consistent with the observed anomalies in the element profile.

The Castle Ashby unsigned urn was one of four apparently identical urns - the other three all signed by Blashfield. Although this urn was believed to be a Blashfield product, there is no documentary evidence for this and the PCA has clearly assigned it to the Doulton group (Fig.7a). Bivariate ratio considerations are consistent with these findings (Fig.5b). This result is not totally surprising as there are many examples of Doulton's work within the grounds of Castle Ashby (e.g. Fig.2). The Doulton urn was most likely purchased as a replacement replica when Blashfield products were no longer available.

The Burghley House unsigned urn, although believed to be a Blashfield product (Burghley Estate), was shown to be significantly different from all three manufacturers, both by PCA (Fig.7b) and the bivariate element ratios (Fig. 5b). There are a number of key elemental differences between the Burghley House urn and the characteristic Blashfield composition. Most notably are significantly elevated levels of barium (an order of magnitude), zirconium $(0.16 \% \mathrm{cf} .0 .034 \%)$, potassium $(2.5 \%$ cf. $0.66 \%$ ) and aluminium ( $7.5 \%$ cf. $2.9 \%$ ), and a much reduced calcium content ( $0.39 \%$ cf. $1.6 \%)$. It is possible that past conservation treatments may be interfering with the material composition, but the good condition of the urn would suggest it to be a much later work, and therefore more likely to be from a different clay source.

The Anglesey Abbey urn is stylistically identical to the Burghley urns (Fig.8) - the latter having the Stamford Terra Cotta Company stamp shown in Figure 1. The urn was therefore believed to be a Blashfield product even though the 'Stamford' part of the stamp was the only evident indentation. However, the PCA shows the urn to have no resemblance to Blashfield (Fig 7c), and the bivariate element ratios put the urn firmly among the Doulton group (Fig.5b). In fact, the data show the urn to have some element concentrations in common with both Blashfield and Doulton, and it even displays the low iron content and no detectable bismuth, characteristic of Coade stone. On close inspection of the urn, however, traces of black paint are visible, which may account for the relatively high lead content observed $(0.19 \%$, cf. $0.020 \%$ in Blashfield). In the 18th and 19th centuries, artefacts were often painted with a brownish-black paint and then polished to create the effect of bronze. Although the analysis points were chosen carefully to avoid any obvious areas of surface change, residues of previous polychromy may well have distorted the element profiles observed. It is also possible that the urn has been manufactured from a different material by another manufacturer following purchase of the Blashfield mould.

It was expected that the Nymph from the fountain at Dunorlan Park, believed to be a clay-based Pulham product, would be readily distinguished from the signed Coade, Blashfield and Doulton products. This was confirmed by the PCA (Fig 9), although the fabric was shown to have some overlap with the Doulton group. This was also reflected in the element ratios (Fig.5b), showing the Nymph to have a loose similarity to the Doulton group. The element profile was indeed very similar to the Doulton fabric, but with some exceptions - low concentrations of iron (0.82\% cf. $1.02 \%)$, aluminium (4.9\% cf. $6.0 \%)$ and phosphorus (0.063 cf. $0.40 \%)$ - making the material statistically distinct.

\section{Conclusions}

Two questions which the study needed to address was whether the heterogeneity of the clay-based materials typically used by the eighteenth and nineteenth century manufacturers of garden statuary 
and ornamentation would adversely affect discrimination between the different materials, and whether the use of a surface analytical technique could produce element profiles which were representative of the material body.

Despite the inherent heterogeneity of these materials, it is evident from the results that discrimination is possible using pXRF, primarily due to the significant differences observed across a range of elements at both macro- and trace-level. The fact that the signed objects of Coade, Blashfield and Doulton produced three distinct and statistically significant groups demonstrates that the data reflect the composition of the bulk material - rather than just surface characteristics.

Through identifying the main discriminators for the Coade, Blashfield and Doulton materials, it was possible to propose a simple presumptive test, through a bivariate plot of two key ratios ( $\mathrm{Sr} / \mathrm{Fe}$ and $\mathrm{Rb} / \mathrm{Zr}$ ), which can be used in an initial evaluation of any unsigned works.

The pXRF element profiles were successfully used to establish the provenance of some unsigned works. Mrs Coade's gate pier, The Sphinx at Croome Park and the legs of George III were confirmed as Coade - although the bust of George III was noticeably different. The unsigned urn at Burghley House was clearly shown not to be a Blashfield product, while the unsigned urn at Castle Ashby was shown to be Doulton.

Not all the results were so satisfactory and the difference between the bust and legs of George III shows to what extent conservation materials can distort the data. This is one of the main limitations of the PXRF technique and highlights the necessity of investigating conservation records and consulting relevant conservators before any analysis takes place. Another limitation of the technique highlighted is that, in the presence of paint, the polychromy will dominate the element profile rather than the underlying material. This was perhaps the difficulty presented by the urn at Anglesey Abbey, where there is still evidence of black paint.

Nevertheless, despite the problems presented by conservation and polychromy, this research has shown that the recipes employed by different manufacturers create unique element profiles which have been used in this study to identify Coade, Blashfield and Doulton products, but also have the potential for identifying other materials. This is helpful for the evaluation of works which are unsigned or where provenance is difficult to establish due to the purchase and copy of moulds. The technique also enables conservation to be carried out on an informed basis. 


\section{Acknowledgements}

The authors would like to thank Lord Faringdon (Buscot Park), Lord Compton (Castle Ashby) and the Burghley House Estate for access to private gardens, and the National Trust, The Landmark Trust and Tunbridge Wells Museum for providing access to their collections.

\section{References}

1. Van Lemmen, H. Architectural Ceramics, Shire Publications, 2002.

2. Freestone, I.C. 'The science of early British porcelain' in Sixth Conference \& Exhibition of the European Ceramic Society (British Ceramic Proceedings 60) (2000) 19-27.

3. Freestone, I., Forgotten but not lost: the secret of Coade Stone, Proc. Geol. Ass., 1991,135-138.

4. Kelly, A. Mrs Coade's Stone, Self Publishing Association Ltd, 1990.

5. Stratton, M., The Terracotta Revival, Victor Gollancz, 1993.

6. Blashfield, J. M., A catalogue of seven hundred articles made in patent terra cotta, and red and cane-coloured pottery, Henry Johnson, Stamford, 1882.

7. Davis, J.P.S., Antique Garden Ornament, Antique Collectors' Club, 1998.

8. Hitching, C., Rock Landscapes: The Pulham Legacy, Antique Collectors' Club, 2012.

9. Freestone, I.C., Bimson, M. and Tite, M.S., The Constitution of Coade Stone, in: Ceramics and Civilization, 1: Ancient Technology to Modern Science, Kingery, W.D. (ed.), 1985, 293-304.

10. Charalambou, A., Kassianidou, V. and Papasavvas, G., A compositional study of Cypriot bronzes dating to the Early Iron Age using portable X-ray fluorescence spectrometry (pXRF), Journal of Archaeological Science, 2014, 46, 2015-2016.

11. Gebremariam,K.F., Kvittingen, L. and Banica, F-G., Application of a portable XRF analyzer to investigate the medieval wall paintings of Yemrehanna Krestos Church, Ethiopia, $X$-Ray Spectrom.,46, 2013, 462-469.

12. Bonizzoni, L., Galli, A. And Milazzo, M., XRF analysis without sampling of Etruscan depurata pottery for provenance classification, $X$-Ray Spectrom., 39 (5), 2010, 346-352

13. Barone, G., Crupi, V., Longo, F., Majolino, D., Mazzoleni, P., Spagnolo, G., Venuti, V. and Aquilia, E., Potentiality of non-destructive XRF analysis for the determination of Corinthian $B$ amphorae provenance, $X$-ray Spectrom., 40, 2011, 333-337.

14. Forster, N., Grave , P., Vickery, N. and Kealhofer, L. Non-destructive analysis using pXRF: methodology and application to archaeological ceramics, $X$-ray spectrom., 40 (5), 2011, 389398. 
Table 1 The twenty-four historic objects chosen for analysis.

\begin{tabular}{|c|c|c|c|c|c|}
\hline Sample & $\mathbf{n}$ & Object & Location (UK) & $\begin{array}{l}\text { Manufacturer's } \\
\text { indentation }\end{array}$ & Additional information \\
\hline AACA 1-7 & 7 & Caryatid (statue) & \multirow{3}{*}{$\begin{array}{l}\text { Anglesey Abbey, } \\
\text { Cambridgeshire }\end{array}$} & \multirow{3}{*}{$\begin{array}{c}\text { Coade Lambeth } \\
1793\end{array}$} & \multirow{3}{*}{-} \\
\hline AACB 1-6 & 6 & Caryatid (statue) & & & \\
\hline AACC 1-6 & 6 & Caryatid (statue) & & & \\
\hline CD 1-6 & 6 & Druid (statue) & $\begin{array}{c}\text { Croome Park, } \\
\text { Worcestershire }\end{array}$ & $\begin{array}{c}\text { Coade London } \\
1793 \\
\end{array}$ & - \\
\hline BEA 1-7 & 7 & Egyptian (statue) & \multirow{2}{*}{$\begin{array}{l}\text { Buscot Park, } \\
\text { Oxfordshire }\end{array}$} & \multirow{2}{*}{$\begin{array}{c}\text { Coade \& Sealy } \\
1800\end{array}$} & \multirow{2}{*}{-} \\
\hline BEB 1-7 & 7 & Egyptian (statue) & & & \\
\hline BA 1-6 & 6 & Garden urn & \multirow[b]{2}{*}{$\begin{array}{l}\text { Burghley House, } \\
\text { Lincolnshire }\end{array}$} & \multirow{2}{*}{$\begin{array}{l}\text { The Stamford } \\
\text { Terra Cotta } \\
\text { Company } \\
\text { (Blashfield's) } \\
\text { Limited, Stamford }\end{array}$} & \multirow[b]{2}{*}{$\begin{array}{l}\text { Estimated date: } \\
1872 \text { - } 1875\end{array}$} \\
\hline BC 1-6 & 6 & Garden urn & & & \\
\hline CABA 1-6 & 6 & Garden urn & \multirow{7}{*}{$\begin{array}{l}\text { Castle Ashby } \\
\text { Northamptonshire }\end{array}$} & \multirow{3}{*}{$\begin{array}{l}\text { J.M. Blashfield } \\
\text { Stamford } 1868\end{array}$} & \multirow{3}{*}{-} \\
\hline CABB 1-6 & 6 & Garden urn & & & \\
\hline CABC 1-6 & 6 & Garden urn & & & \\
\hline CADA 1-6 & 6 & Garden urn & & \multirow{2}{*}{$\begin{array}{c}\text { Doulton \& Co } \\
\text { Lambeth London }\end{array}$} & \multirow{2}{*}{$\begin{array}{c}\text { Estimated date: } \\
1854 \text { - } 1890 \\
\end{array}$} \\
\hline CADB 1-6 & 6 & Garden urn & & & \\
\hline CADC 1-6 & 6 & Garden urn & & \multirow{2}{*}{$\begin{array}{c}\text { Doulton \& Co } \\
\text { Limited Lambeth }\end{array}$} & \multirow{2}{*}{$\begin{array}{c}\text { Estimated date: } \\
1890 \text { - } 1902 \\
\end{array}$} \\
\hline CADD 1-6 & 6 & Garden urn & & & \\
\hline ASL 1-8 & 8 & Lion (statue) & $\begin{array}{c}\text { Temple Gardens } \\
\text { Lincoln }\end{array}$ & $\begin{array}{c}\text { Austin \& Seeley } \\
\text { London }\end{array}$ & $\begin{array}{c}\text { Estimated date: } \\
1870 \\
\end{array}$ \\
\hline GP 1 - 9 & 9 & Gate Pier & $\begin{array}{l}\text { Mrs Coade's Villa } \\
\text { Lyme Regis }\end{array}$ & Not present & Assumed Coade \\
\hline CSp $1-6$ & 6 & Sphinx (statue) & $\begin{array}{c}\text { Croome Park, } \\
\text { Worcestershire }\end{array}$ & Not present & $\begin{array}{c}\text { Assumed Coade } \\
\text { Documentary Evidence [8] }\end{array}$ \\
\hline GIII 1 - 6 & 6 & George III (Bust) & $\begin{array}{l}\text { Lincoln Castle } \\
\text { (garden) } \\
\text { Lincoln }\end{array}$ & Not present & $\begin{array}{l}\text { Assumed Coade \& Sealy, } \\
1810 \\
\text { Documentary Evidence[8] }\end{array}$ \\
\hline GC 1 - 12 & 12 & $\begin{array}{l}\text { George III } \\
\text { (Legs) }\end{array}$ & $\begin{array}{c}\text { Lincoln Castle } \\
\text { (cellar) } \\
\text { Lincoln } \\
\end{array}$ & Not present & $\begin{array}{c}\text { Assumed Coade \& Sealy, } \\
1810 \\
\text { Documentary Evidence[8] }\end{array}$ \\
\hline CAuD 1 - 6 & 6 & Garden urn & $\begin{array}{l}\text { Castle Ashby } \\
\text { Northamptonshire }\end{array}$ & Not present & $\begin{array}{l}\text { One of a group of four urns. } \\
\text { The other three were all } \\
\text { signed Blashfield products }\end{array}$ \\
\hline BB $1-6$ & 6 & $\begin{array}{l}\text { Garden urn (copy } \\
\text { of Warwick vase) }\end{array}$ & $\begin{array}{c}\text { Burghley, } \\
\text { Lincolnshire }\end{array}$ & Not present & $\begin{array}{l}\text { Believed to be a Blashfield } \\
\text { product (Burghley Estate) }\end{array}$ \\
\hline AAU 1-10 & 10 & Garden urn & $\begin{array}{l}\text { Anglesey Abbey, } \\
\text { Cambridgeshire }\end{array}$ & Not present & $\begin{array}{l}\text { 'Stamford' indentation } \\
\text { suggests a Blashfield } \\
\text { product }\end{array}$ \\
\hline P1-12 & 12 & Nymph & $\begin{array}{c}\text { Dunorlan Park, } \\
\text { Kent }\end{array}$ & Not present & $\begin{array}{c}\text { Pulham product, } 1862 \\
\text { Documentary Evidence [5] }\end{array}$ \\
\hline
\end{tabular}


Table 2 Heterogeneity of element concentrations at the surface of the ceramic artefacts using multiple pXRF measurements ( $n=6-12$ ). The spread in elemental concentrations is expressed as the relative standard deviation (RSD\%)

\begin{tabular}{|c|c|c|c|c|c|c|c|c|c|c|c|c|c|c|c|c|c|c|c|c|c|c|c|c|}
\hline \multirow{2}{*}{ SAMPLE } & \multirow{2}{*}{$\mathbf{n}$} & \multicolumn{23}{|c|}{ ELEMENT (RSD\%) } \\
\hline & & $\mathrm{Ba}$ & Sn & $\mathrm{Nb}$ & $\mathrm{Zr}$ & $\mathrm{Sr}$ & $\mathbf{R b}$ & As & $\mathrm{Pb}$ & $\mathrm{Zn}$ & $\mathrm{Cu}$ & $\mathrm{Ni}$ & $\mathrm{Fe}$ & $\mathrm{Mn}$ & $\mathrm{Cr}$ & v & $\mathrm{Ti}$ & $\mathrm{Ca}$ & K & Al & $\mathbf{P}$ & $\mathrm{Si}$ & $\mathrm{Cl}$ & S \\
\hline AACA & 7 & 15 & 224 & 44 & 8.5 & 7.8 & 7.8 & 166 & 85 & 21 & 55 & 71 & 4.2 & 22 & 54 & 41 & 13 & 22 & 35 & 29 & 33 & 28 & 64 & 50 \\
\hline AACB & 6 & 7.2 & 79 & 0.0 & 5.8 & 8.4 & 0.0 & 121 & 62 & 54 & 63 & 50 & 4.1 & 18 & 21 & 32 & 12 & 34 & 3.3 & 19 & 20 & 22 & 112 & 64 \\
\hline AACC & 6 & 3.4 & 30 & 78 & 7.7 & 7.8 & 8.4 & 64 & 53 & 24 & 51 & 52 & 6.3 & 16 & 30 & 12 & 9.4 & 20 & 28 & 30 & 28 & 6.0 & 70 & 50 \\
\hline$C D$ & 6 & 6.5 & 25 & 0.0 & 5.7 & 10 & 0.0 & 58 & 23 & 29 & 24 & 155 & 13 & 22 & 55 & 40 & 11 & 62 & 35 & 30 & 46 & 4.0 & 125 & 47 \\
\hline BEA & 7 & 5.9 & 36 & 0.0 & 7.0 & 8.6 & 12 & 173 & 80 & 111 & 52 & 23 & 5.7 & 15 & 28 & 12 & 5.2 & 25 & 23 & 28 & 20 & 11 & 75 & 101 \\
\hline BEB & 7 & 7.8 & 47 & 70 & 9.3 & 3.8 & 0.0 & 0.0 & 33 & 35 & 68 & 76 & 7.6 & 46 & 28 & 16 & 8.2 & 25 & 18 & 27 & 51 & 15 & 50 & 33 \\
\hline CADA & 6 & 7.0 & 118 & 0.0 & 0.0 & 6.1 & 0.0 & 18 & 17 & 26 & 29 & 74 & 1.0 & 20 & 26 & 9.0 & 5.6 & 26 & 6.5 & 12 & 24 & 8.1 & 1.6 & 24 \\
\hline CADB & 6 & 4.4 & 113 & 0.0 & 2.7 & 11 & 8.4 & 59 & 56 & 71 & 45 & 86 & 9.5 & 22 & 23 & 36 & 4.4 & 33 & 9.4 & 18 & 40 & 13 & 29 & 30 \\
\hline CADC & 6 & 2.4 & 155 & 0.0 & 2.9 & 7.9 & 0.0 & 63 & 32 & 95 & 12 & 29 & 6.6 & 22 & 13 & 40 & 6.3 & 32 & 13 & 14 & 62 & 13 & 23 & 58 \\
\hline CADD & 6 & 2.4 & 167 & 0.0 & 3.0 & 9.8 & 0.0 & 45 & 43 & 60 & 51 & 54 & 2.8 & 22 & 18 & 47 & 5.1 & 13 & 4.5 & 17 & 62 & 14 & 67 & 17 \\
\hline CABA & 6 & 7.6 & 0.0 & 19 & 1.7 & 7.0 & 0.0 & 58 & 42 & 0.0 & 14 & 51 & 6.0 & 21 & 36 & 12 & 14 & 20 & 25 & 30 & 13 & 8.5 & 32 & 38 \\
\hline CABB & 6 & 5.1 & 0.0 & 0.0 & 3.2 & 6.6 & 11 & 86 & 19 & 29 & 51 & 57 & 4.6 & 21 & 13 & 17 & 13 & 39 & 16 & 49 & 50 & 9.2 & 29 & 17 \\
\hline CABC & 6 & 6.6 & 0.0 & 0.0 & 2.3 & 0.0 & 0.0 & 45 & 24 & 10 & 28 & 52 & 4.4 & 20 & 22 & 8.2 & 2.5 & 17 & 18 & 25 & 33 & 7.5 & 28 & 31 \\
\hline BA & 6 & 17 & 0.0 & 19 & 4.5 & 6.2 & 11 & 29 & 38 & 13 & 23 & 19 & 9.0 & 11 & 31 & 39 & 13 & 26 & 36 & 48 & 95 & 30 & 20 & 22 \\
\hline$B C$ & 6 & 4.9 & 0.0 & 22 & 6.6 & 0.0 & 19 & 49 & 23 & 13 & 24 & 19 & 4.1 & 24 & 13 & 54 & 6.8 & 25 & 20 & 17 & 45 & 21 & 31 & 32 \\
\hline MEAN & & 6.9 & 109 & 17 & 4.7 & 6.7 & 5.2 & 69 & 42 & 39 & 39 & 58 & 5.9 & 21 & 27 & 28 & 8.6 & 28 & 19 & 26 & 41 & 14 & 50 & 41 \\
\hline
\end{tabular}


Table 3 Statistically significant differences in mean element concentrations between the Coade (C), Blashfield (B) and Doulton (D) materials following ANOVA with Tukey pairwise comparisons (95\% simultaneous confidence intervals). Significance is accepted for $P<0.001$.

\begin{tabular}{|c|c|c|c|c|}
\hline \multirow{2}{*}{ Element } & \multirow{2}{*}{$\begin{array}{c}\text { Significance } \\
\boldsymbol{p}\end{array}$} & \multicolumn{3}{|c|}{$\begin{array}{c}\text { Significance identified in pairwise } \\
\text { comparisons }\end{array}$} \\
\cline { 3 - 5 } & & $\mathbf{C / B}$ & $\mathbf{C / D}$ & $\mathbf{B} / \mathbf{D}$ \\
\hline $\mathrm{Ba}$ & $<0.0005$ & $\sqrt{ }$ & $\sqrt{ }$ & $\sqrt{ }$ \\
\hline $\mathrm{Zr}$ & $<0.0005$ & $\sqrt{ }$ & $\mathrm{X}$ & $\sqrt{ }$ \\
\hline $\mathrm{Sr}$ & $<0.0005$ & $\sqrt{ }$ & $\sqrt{ }$ & $\mathrm{X}$ \\
\hline $\mathrm{Rb}$ & $<0.0005$ & $\sqrt{ }$ & $\mathrm{X}$ & $\sqrt{ }$ \\
\hline $\mathrm{Fe}$ & $<0.0005$ & $\sqrt{ }$ & $\sqrt{ }$ & $\mathrm{X}$ \\
\hline $\mathrm{Ti}$ & $<0.0005$ & $\sqrt{ }$ & $\sqrt{ }$ & $\sqrt{ }$ \\
\hline $\mathrm{K}$ & $<0.0005$ & $\sqrt{ }$ & $\sqrt{ }$ & $\sqrt{ }$ \\
\hline $\mathrm{Al}$ & $<0.0005$ & $\sqrt{ }$ & $\sqrt{ }$ & $\sqrt{ }$ \\
\hline $\mathrm{Bi}$ & $<0.0005$ & $\sqrt{ }$ & $\sqrt{ }$ & $\sqrt{ }$ \\
\hline $\mathrm{P}$ & $<0.0005$ & $\mathrm{X}$ & $\sqrt{ }$ & $\sqrt{ }$ \\
\hline
\end{tabular}




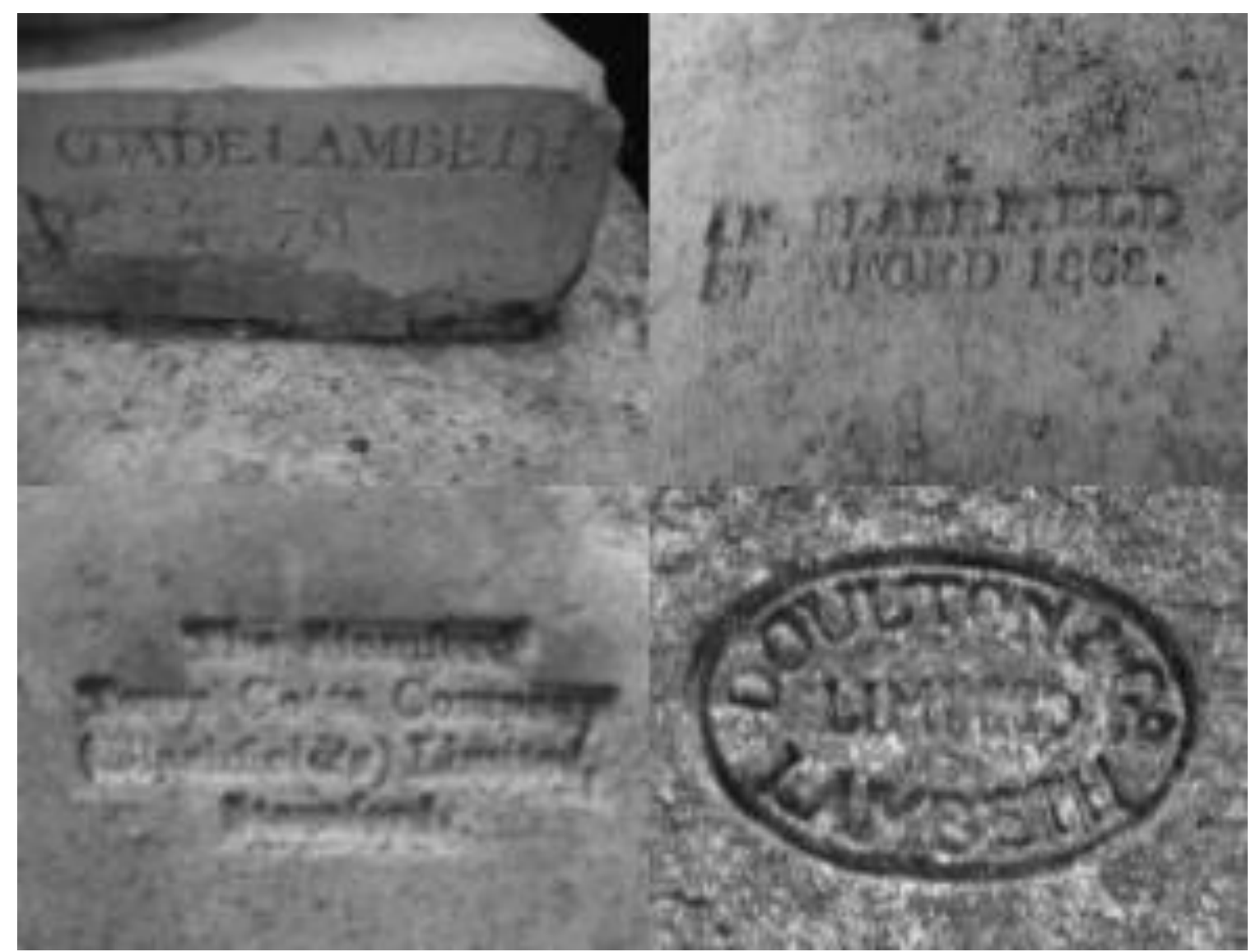

Figure 1 Examples of manufacturer's stamps on ceramic objects. Clockwise from the top left: Coade Lambeth 1779 (AACA, AACB, AACC); J.M. Blashfield Stamford 1868 (CABA, CABB, CABC); The Stamford Terra Cotta Company (Blashfield) Limited, Stamford (1872-5) (BA, BC); Doulton \& Co Ltd Lambeth (1890-1902)(CADA, CADB, CADC, CADD) 
Figure 2 Examples of garden statuary and ornaments selected for in-situ analysis. Left: Caryatid, Coade Lambeth 1793 (Anglesey Abbey, Cambridgeshire, UK); and right: Garden urn, Doulton \& Co. Lambeth London 1854-1890 (Castle Ashby, Northamptonshire, UK)

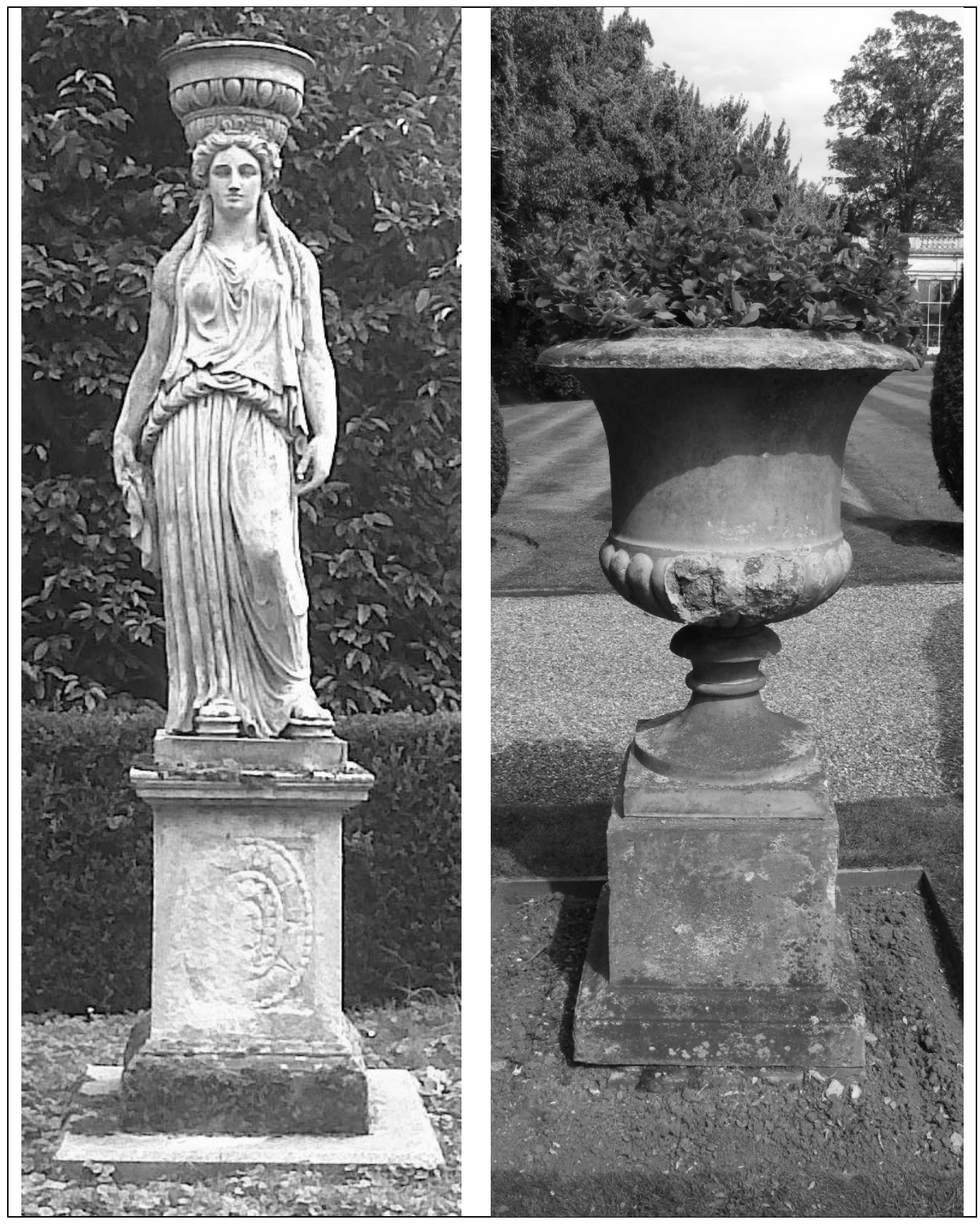


Figure 3 Bielemental plot using pXRF data for samples of Coade, Blashfield and Doulton, indicating that bulk differences in the ceramic material is reflected in the surface analysis.

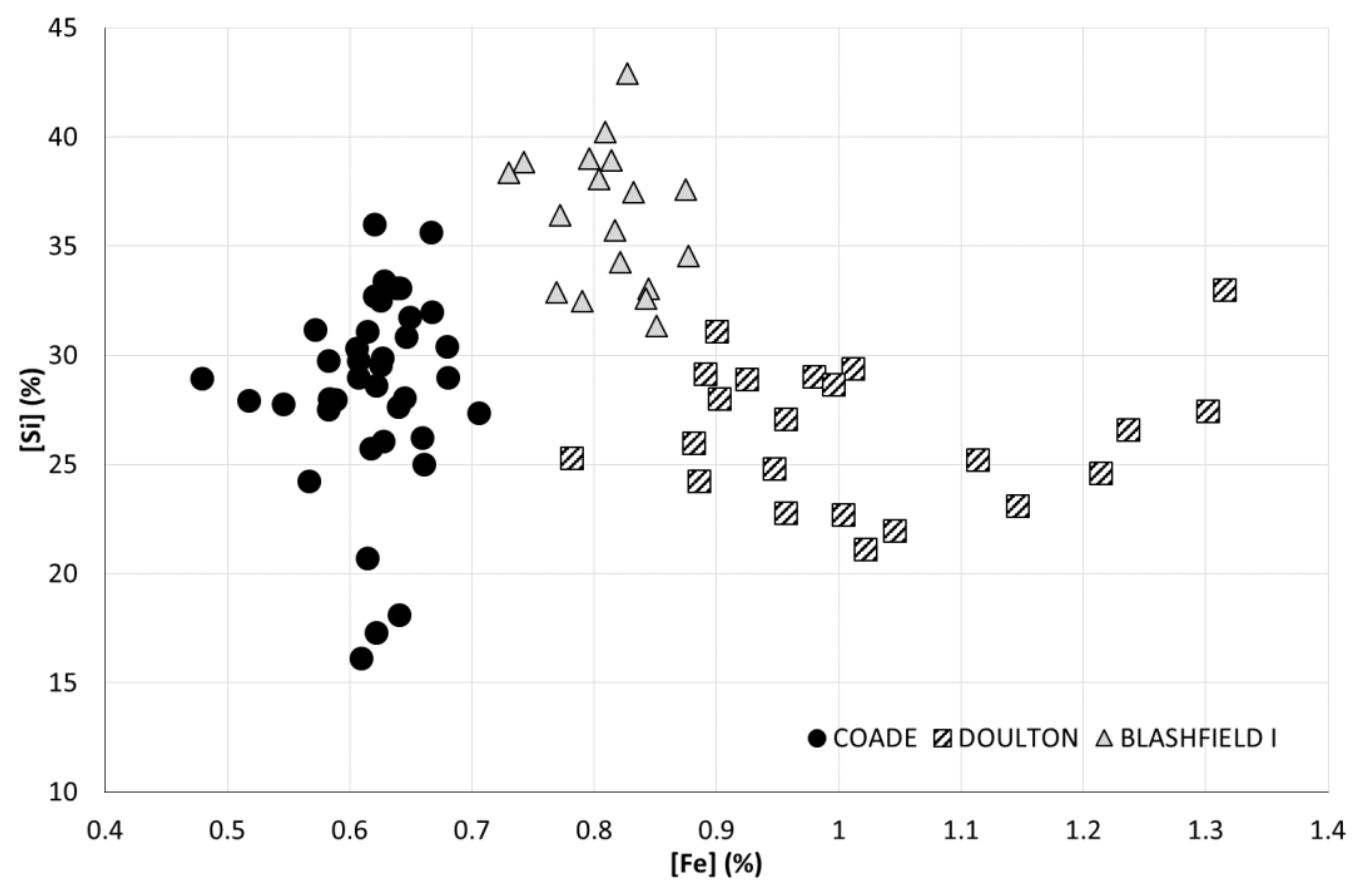


Figure 4 PCA of all signed Coade, Blashfield and Doulton ceramic artefacts (top) showing the first two principal components. Comparison with Austin \& Seeley artefacts (below) indicates the different nature of the cementitious manufacturing material

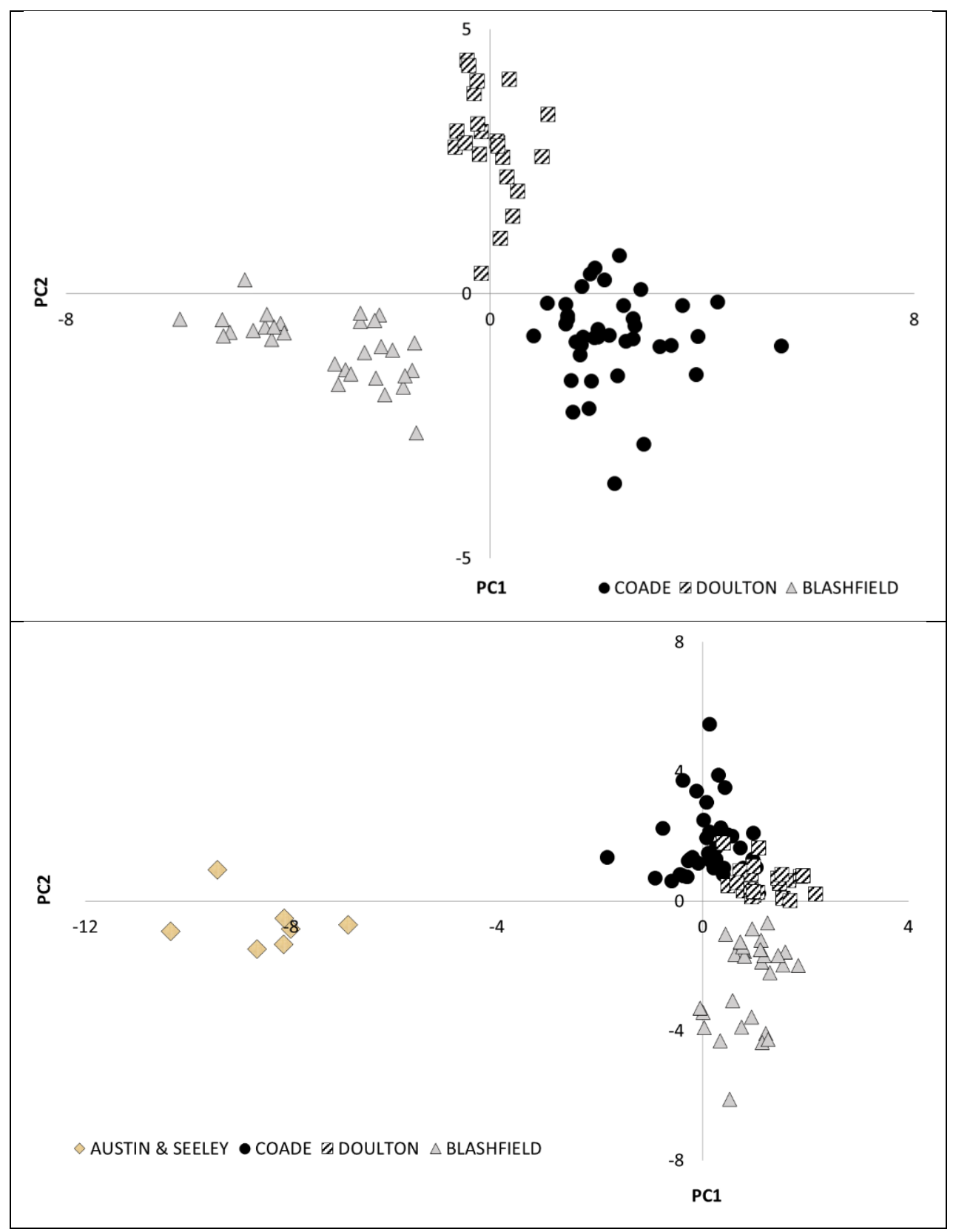


Figure 5 Characteristic compositional differences between Coade, Blashfield and Doulton, showing (a) the ten principal element discriminators identified for the three materials and (b) a simple bivariate ratio differential, using mean concentrations. The unsigned works are included for comparison.

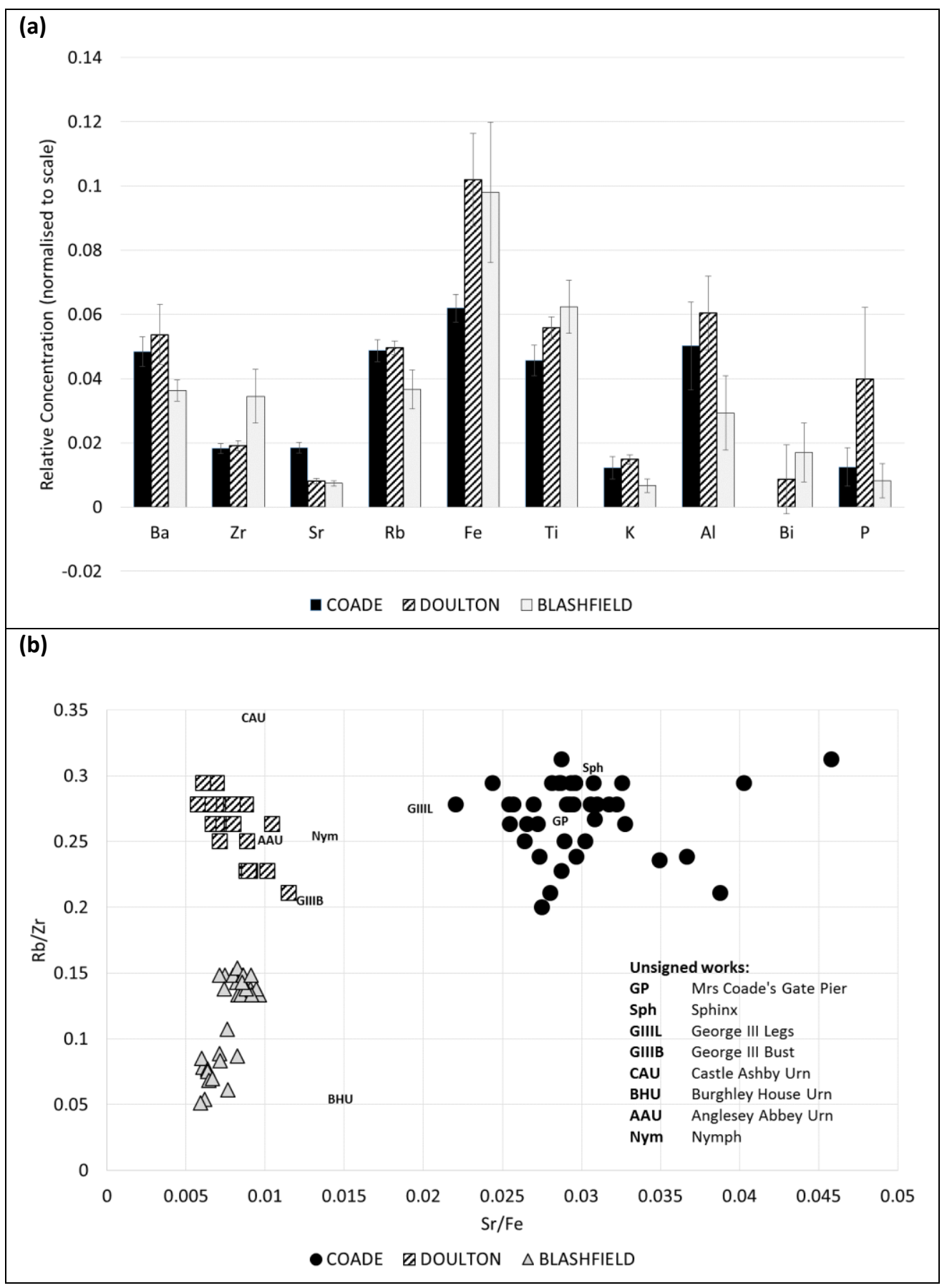


Figure 6 PCA of unsigned artefacts against the characteristic groups of Coade, Blashfield and Doulton (a) the Gate pier at Mrs Coade's villa; (b) The Sphinx at Croome Park; (c) George III legs, still in original condition; and (d) George III bust following extensive conservation treatment. Documentary evidence [8] show these artefacts to be of Coade origin. The statue of George III is believed to be from Coade \& Sealy, 1810.

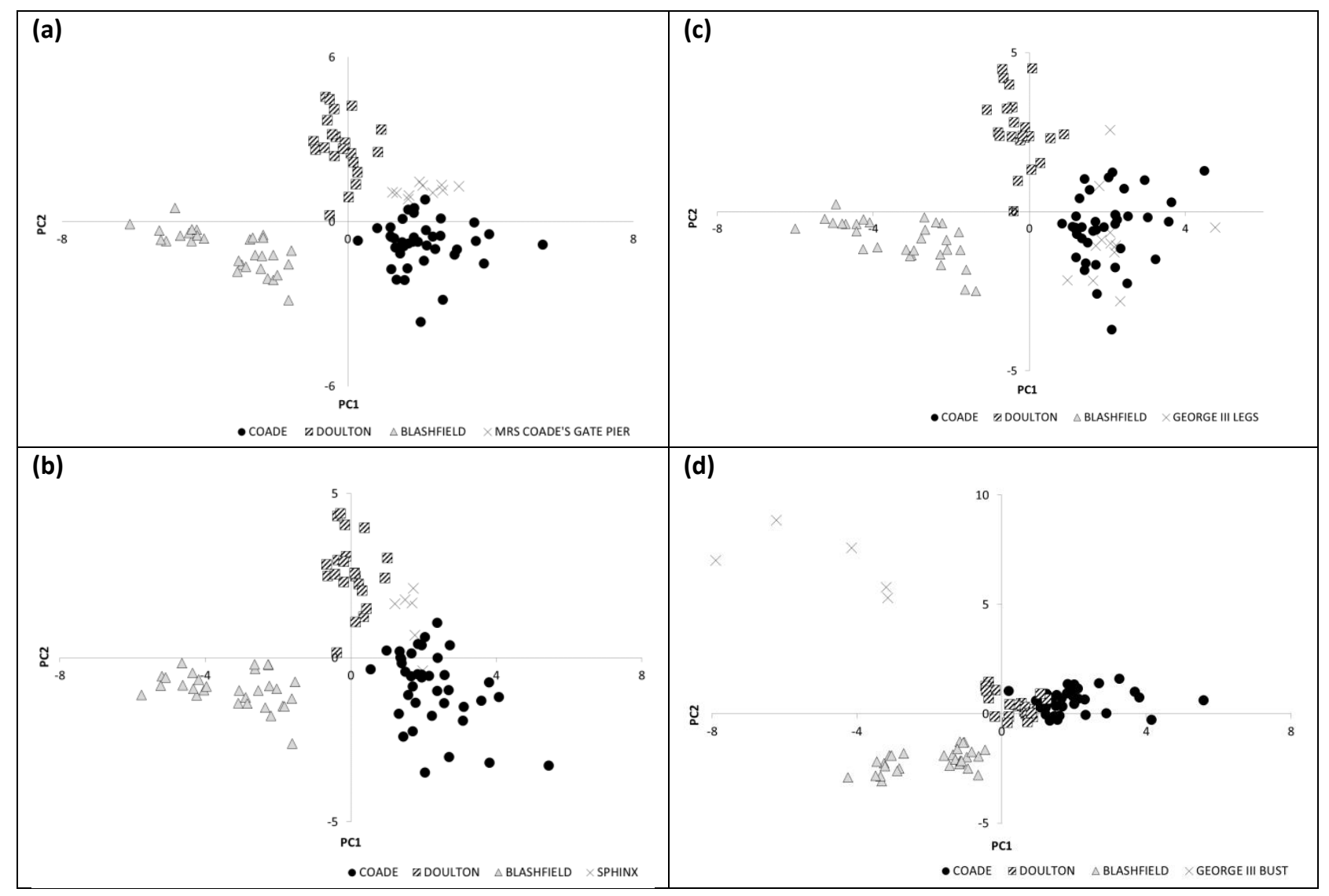


Figure 7 PCA of unsigned urns against the characteristic groups of Coade, Blashfield and Doulton (a) from Castle Ashby; (b) from Burghley House; and (c) from Anglesey Abbey. All were believed to be of Blashfield origin.

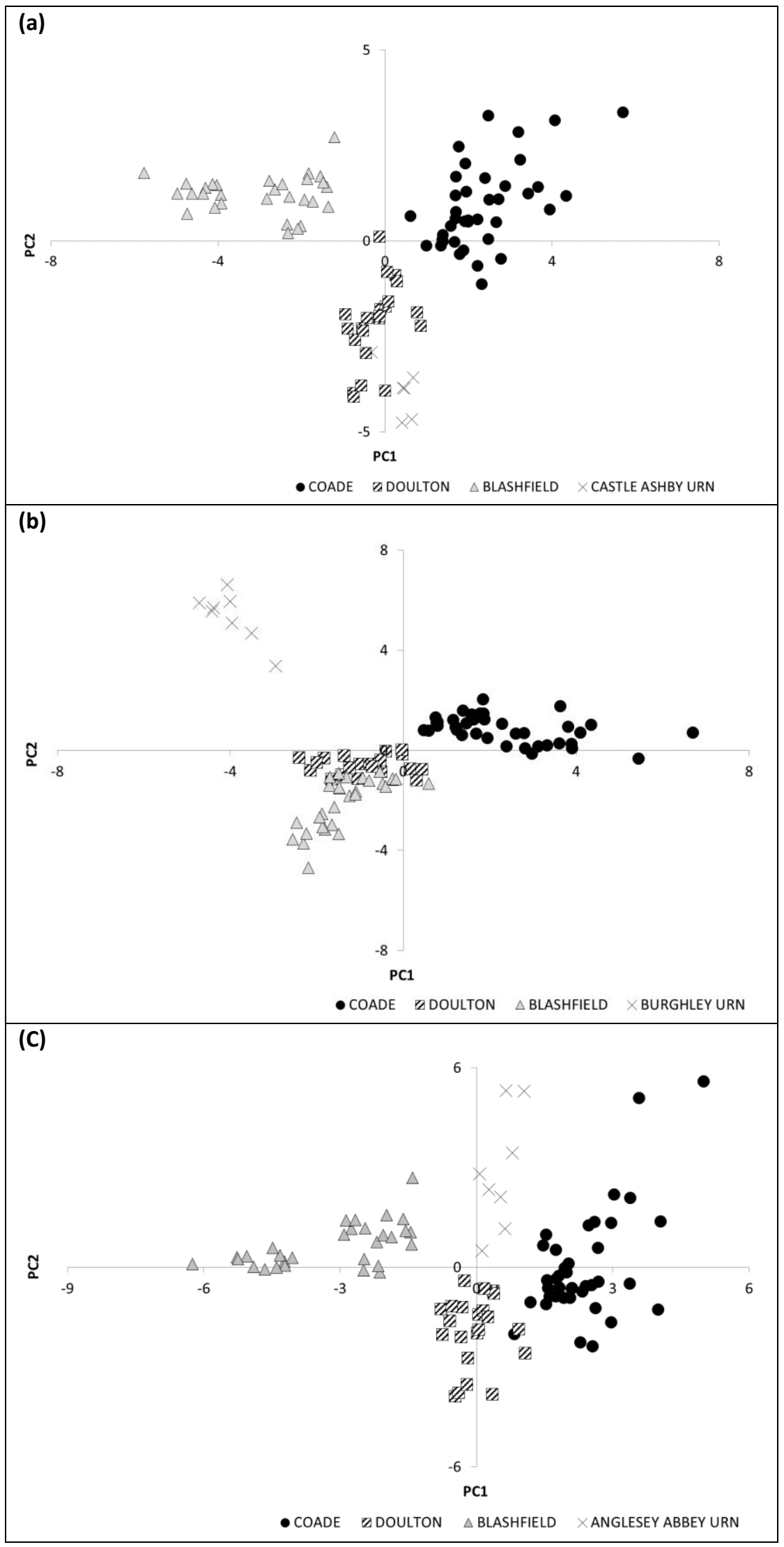


Figure 8 Comparison of the garden urns from Anglesey Abbey (AAU) (left) and Burghley House (BA, BC) (right). The Burghley urns are clearly marked with the Blashfield manufacturer's stamp.

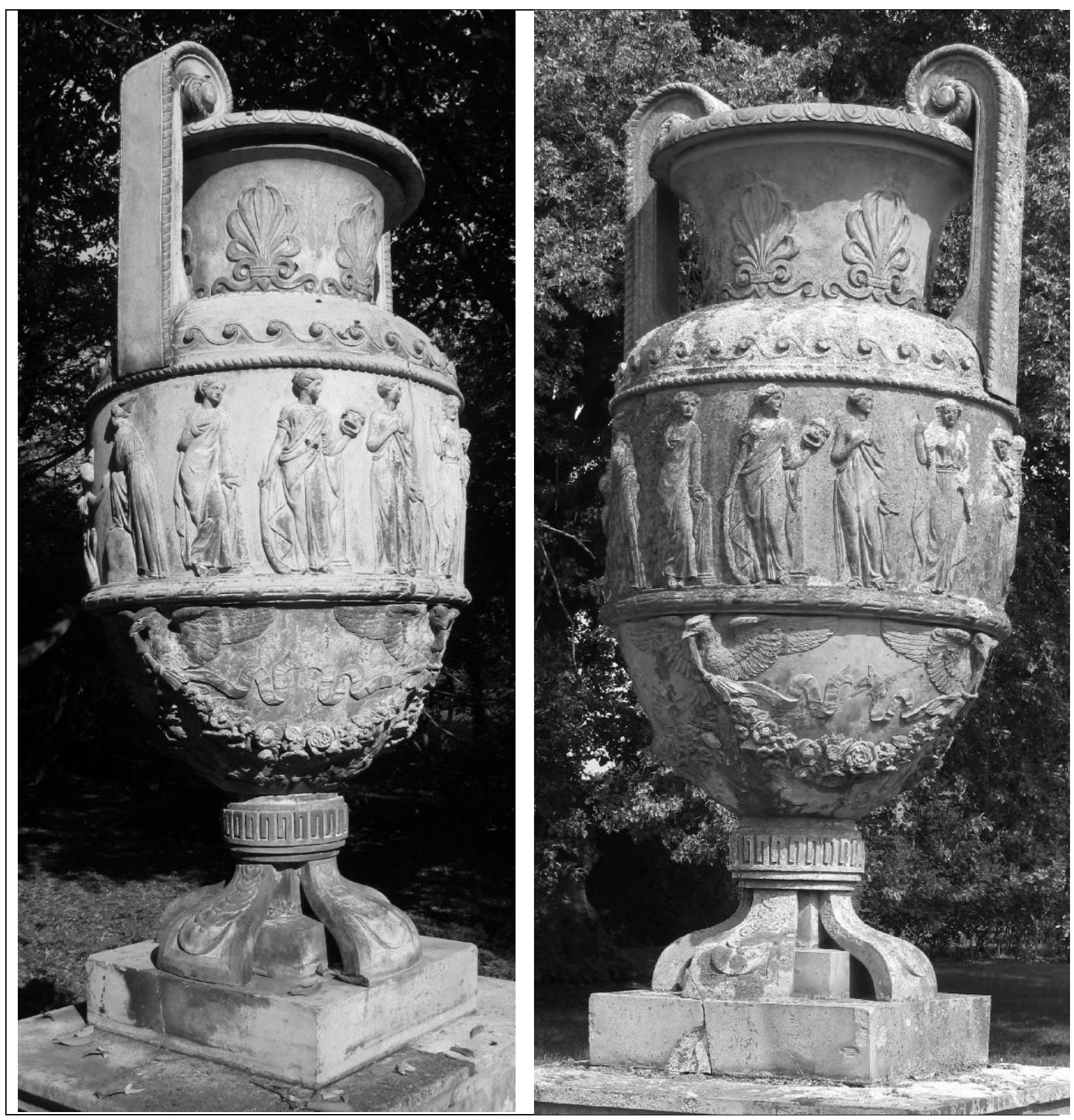


Figure 9 PCA of the unsigned fountain Nymph from Dunorlan Park against the characteristic groups of Coade, Blashfield and Doulton. The Nymph is believed to be a Pulham product from 1862 [5].

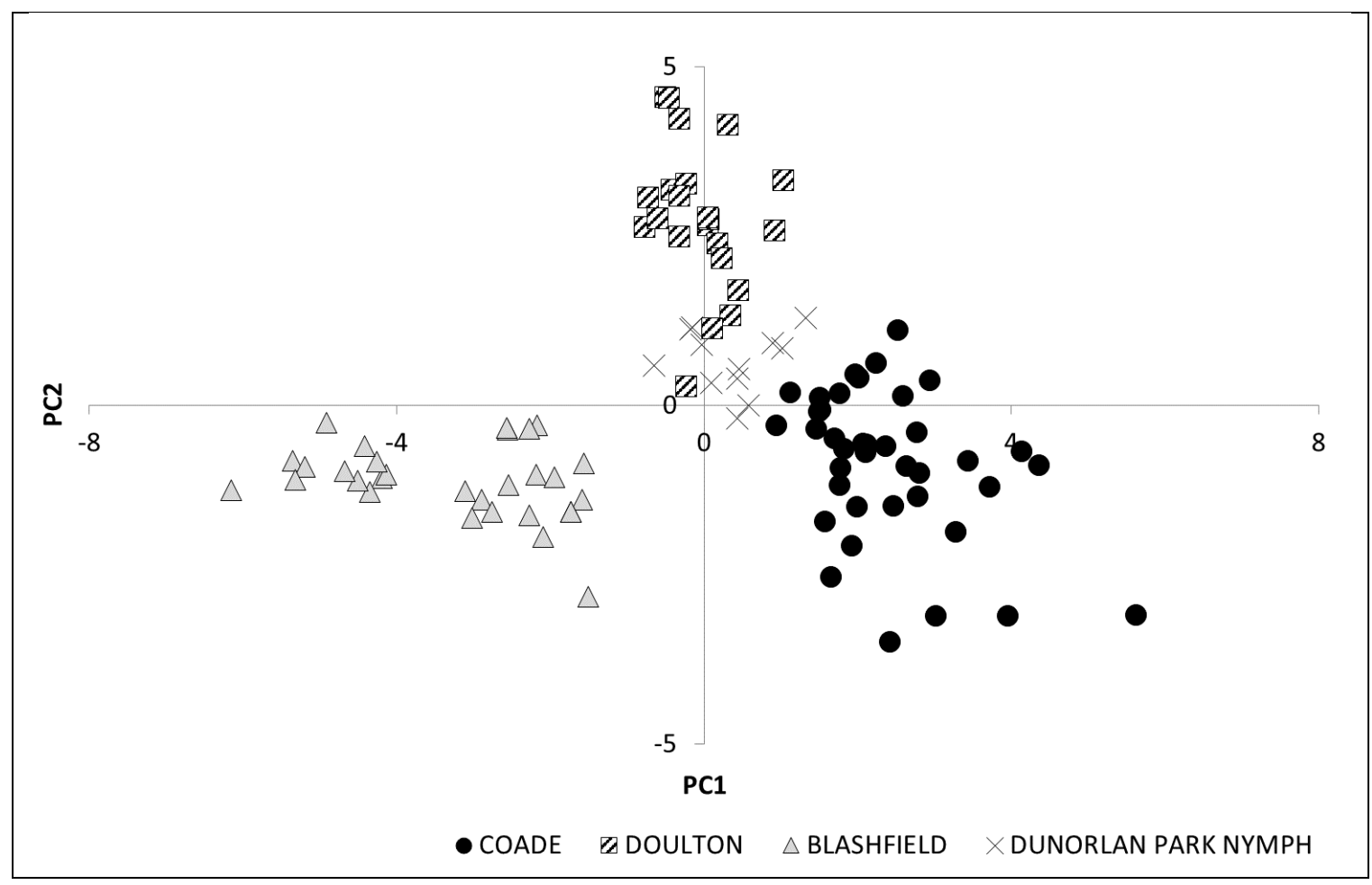

